\title{
Cyclic amidines as precursors for imidazoles
}

\author{
Marc Y. Stevens, ${ }^{* a}$ Ewa Rozycka-Sokolowska, ${ }^{b}$ Gabriella Andersson, ${ }^{a}$ Luke R. Odell, ${ }^{a}$ \\ Bernard Marciniak, ${ }^{b}$ and John A. Joule ${ }^{c}$ \\ ${ }^{a}$ Division of Organic Pharmaceutical Chemistry, Department of Medicinal Chemistry, \\ BMC, Box 574, Uppsala University, S-75123, Uppsala, Sweden \\ ${ }^{b}$ Institute of Chemistry, Environmental Protection and Biotechnology, Jan Dtugosz University, \\ 42-200 Czestochowa, Poland \\ ${ }^{c}$ The School of Chemistry, The University of Manchester, Manchester M13 9PL, UK \\ E-mail: marc.stevens@orgfarm.uu.se
}

DOI: http://dx.doi.org/10.3998/ark.5550190.p009.134

\begin{abstract}
The regioselective nucleophilic reactivity of cyclic amidines is considered in the context of their reactions with 2-haloketones to generate imidazoles. Since the tautomer with an endocyclic imine is favoured, reaction with the 2-haloketone electrophile proceeds via initial alkylation at the ring nitrogen. This was confirmed by repeating a suitable literature reaction and submitting the isolated product to single-crystal X-ray analysis.
\end{abstract}

Keywords: Imidazole synthesis, cyclic amidine, regioselectivity, single-crystal analysis

\section{Introduction}

The best-known method for the ring synthesis of imidazoles ${ }^{1-4}$ involves the interaction of an amidine 2 and a 2-halo-ketone 1, with elimination of hydrogen halide and water, giving a 2,4(5)disubstituted imidazole $\mathbf{3}$ (Scheme 1). ${ }^{5}$

Usually, amidines are handled as their resonance-stabilised amidinium salts, $\mathbf{4}$, being easily converted into the free amidine with mild base. 2-Hydroxy-aldehydes (sugars) also react in like fashion with formamidine acetate, to produce 4(5)-substituted imidazoles. ${ }^{6,7}$ 


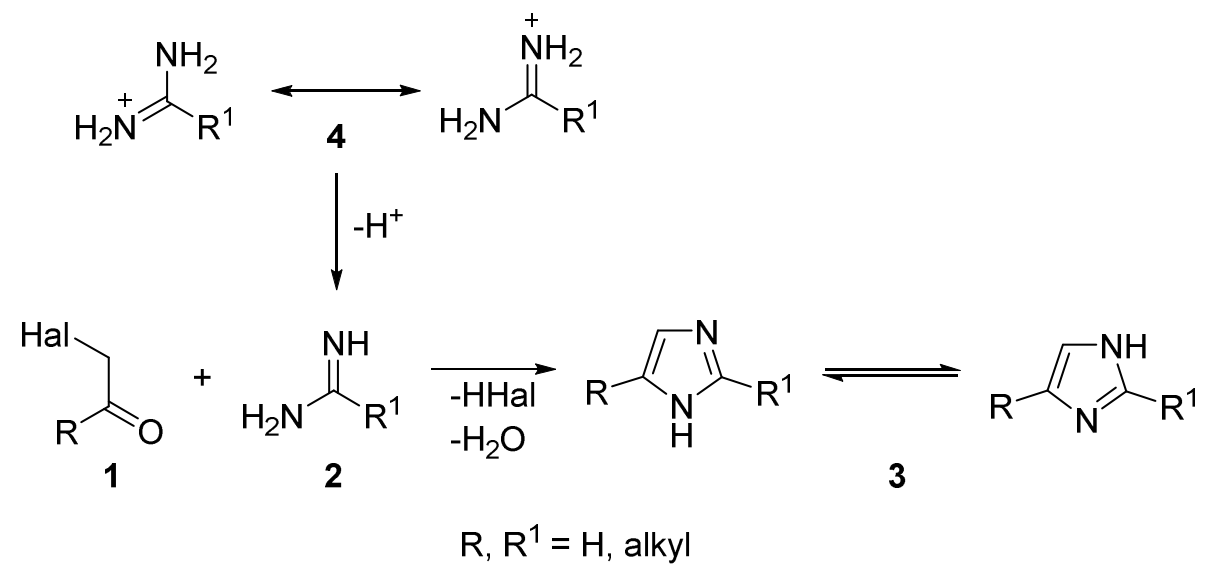

Scheme 1. General reaction of an amidine with a 2-halo-ketone.

In considering the details of these cyclisation processes, one must remember that the initial interaction of an amidine with an electrophile always involves the imine nitrogen as nucleophile, since this selectivity allows a resonance stabilized amidinium intermediate to be generated. Since amidines are tautomeric, consideration of the regiochemistry with which they react must also take account of the possibility that the minor tautomer might have the more reactive imine nitrogen centre. Considering $N$-monosubstituted amidines $\mathbf{4}$, when the electrophile is a proton, each tautomer gives rise to the same amidinium cation $\mathbf{5}$; for other electrophiles ( $\mathrm{E}^{+}$in Scheme 2 ) different products, 6 and 7, can arise.

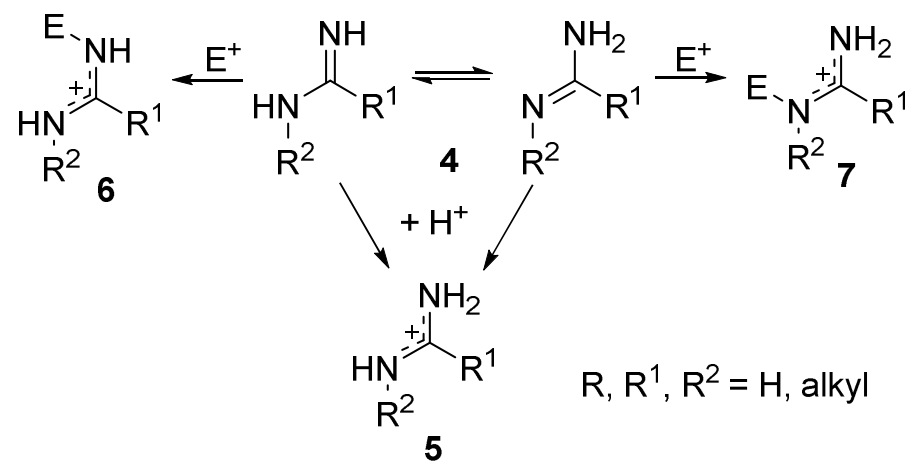

Scheme 2. General reaction of an $N$-substituted amidine with an electrophile.

Thus, for the standard imidazole-forming process by the combination of a 2-haloketone and an amidine (Scheme 1), the first intermediate will have the form 8 (Scheme 3). Indeed, in one instance, ${ }^{8}$ such an intermediate salt was isolated before completion of the ring closure in a second step. 


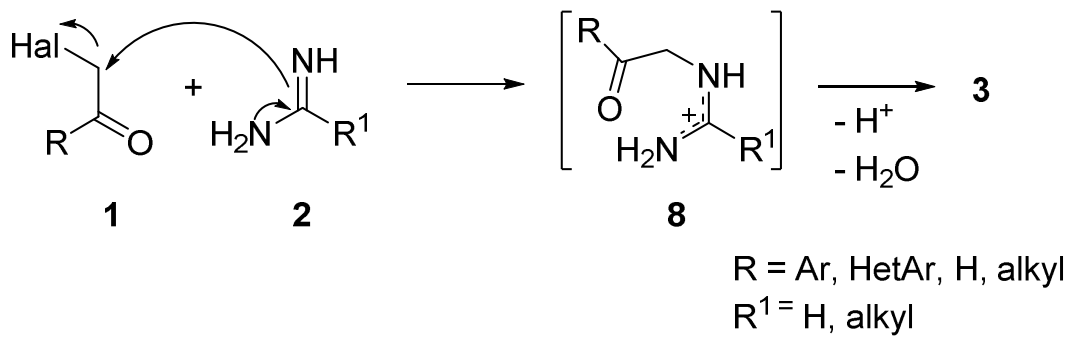

Scheme 3. First step in the reaction between an amidine and a 2-halo-ketone.

Imidazoles can also be synthesized via the reaction of an amidine with 2-halo-3-alkoxy-2propenals, e.g. 9 (surrogates for 3-halo-pyruvaldehydes) producing formylimidazoles. With $\mathrm{N}$ mono-alkyl amidines 4, mixtures of isomeric aldehydes $\mathbf{1 0}$ and $\mathbf{1 1}$ in ratios varying from 85:15 to 100:0 were obtained (Scheme 4). ${ }^{9}$ Based on the analysis above, it seems that both tautomers of 4 are available for reaction and that $\mathbf{4 a}$ reacts more rapidly than $\mathbf{4 b}$. Thus the observed regioselectivity is interpreted as meaning that the initial (and product/regioisomer-determining) step is nucleophilic attack by the imine nitrogen of tautomer $4 \mathbf{a}$ at the electrophilic C-3 carbon of $\mathbf{9}$. Studies of the tautomeric equilibria of $N$-mono-alkyl-substituted amidines (substantiated by studies of $N$-alkyl- $N$ '-aryl-disubstituted amidines ${ }^{10}$ ) show that the isomer with the alkyl group on the amino nitrogen is usually the more stable, ${ }^{11-13}$ whereas the reverse is true for $N$-mono-aryl amidines. ${ }^{14}$ Therefore, in the latter case, it is the more stable amidine through which reaction leading to the main products of ring closure occurs.

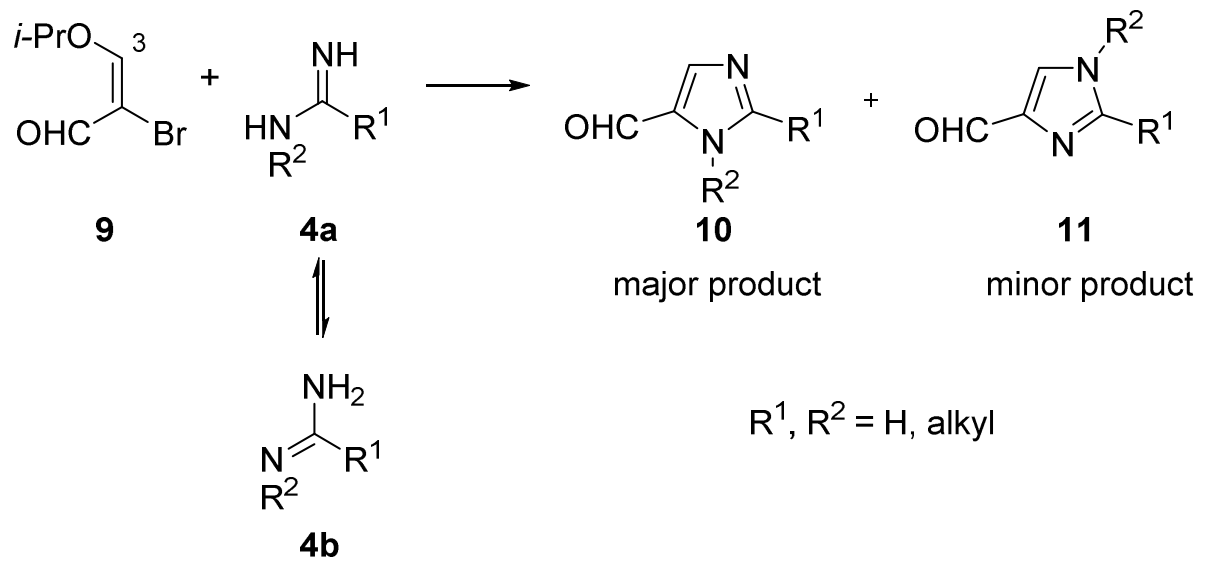

Scheme 4. Reaction of a 2-halo-3-alkoxy-2-propenal with an $N$-substituted amidine.

\section{Results and Discussion}

Our interest in this area was initiated by sundry reports, ${ }^{8,15-17}$ mainly in the patent literature, ${ }^{18}$ describing the reaction of the cyclic amidine 3,4-dihydro- $2 \mathrm{H}$-pyrrol-5-amine (variously referred to as '2-iminopyrrolidine' and '2-aminopyrroline') (12) with a 2-haloketone. Although the 
majority of these reports concur that the products are 2-substituted 6,7-dihydro-5H-pyrrolo1,2-a] imidazoles 13 (Scheme 5), a 2013 patent ${ }^{19}$ reports formation of 3-substituted analogues 14 by the reaction of $\mathbf{1 2}$ with 2-bromo-ketones.

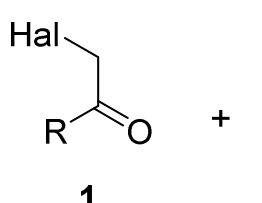

1

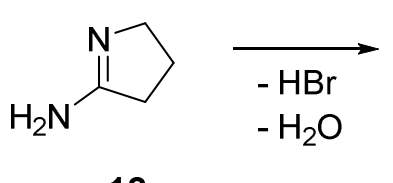

12<smiles>[R]c1cn2c(n1)CCCC2</smiles><smiles>[R]c1cnc2n1CCC2CC</smiles>

$\mathrm{R}=\mathrm{Ar}, \operatorname{Het} \mathrm{Ar}$

Scheme 5. Formation of bicyclic imidazoles from 3,4-dihydro- $2 H$-pyrrol-5-amine (12) and 2-halo-ketones.

There are also reports ${ }^{20,21}$ of six-membered cyclic amidines, e.g. 3,4,5,6-tetrahydropyridin-2amine (15), reacting with 2-bromo-ketones to generate 2-substituted 5,6,7,8-tetrahydroimidazo[1,2-a]pyridines $\mathbf{1 6}$ (Scheme 6), in analogy to the five-membered system.

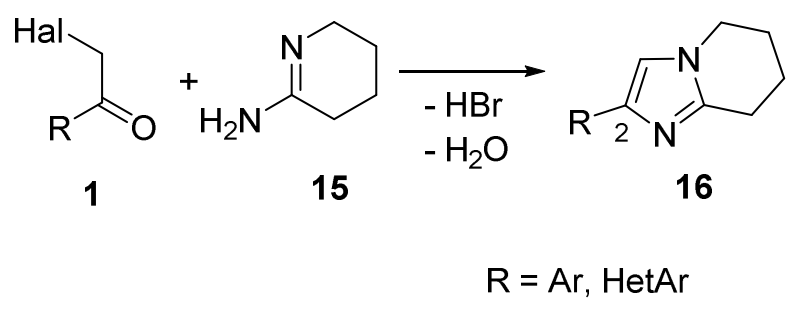

Scheme 6. Formation of bicyclic imidazoles from 3,4,5,6-tetrahydropyridin-2-amine (15) and 2halo-ketones.

Based on studies referred to above, and ignoring any influence that the ring structure may exert, one might expect $\mathbf{1 2}$ and $\mathbf{1 5}$ to exist predominantly in the imino forms, 12-imino and 15imino, i.e. with the alkyl substituent (the ring methylene) on the amino nitrogen (Figure 1). Thus, the imino form 12-imino was used to rationalize the formation of 2,6-piperidinedione by reaction with hypochlorite. ${ }^{22}$ The imino tautomeric form of two antibacterial natural products, 2-imino-3methylene-5-L(carboxy-L-valyl)-pyrrolidine, and 2-imino-3-methylene-5-L-(carboxy-L-threoninyl)-pyrrolidine, seems firmly based, though clearly there are additional factors in these cases. ${ }^{23}$<smiles>C=CC1CCCN1</smiles><smiles>NC1=NCCC(C=C2CCCCC2)C1</smiles> 
Figure 1. Possible tautomers of 3,4-dihydro-2H-pyrrol-5-amine (12) and 3,4,5,6tetrahydropyridin-2-amine (15).

Papers $^{24,25}$ dealing with '2-iminoazaheterocycles' as inhibitors of nitric oxide synthase isoforms also represent five-, six-, seven-, eight-, and nine-membered isomers with an exocyclic imine unit. However, although the papers refer to the biological activities of these iminoazaheterocycles, the experimental details make clear that it is actually their protic salts (cf. 4, 2) that are used in the bioassays; no indication is given of conversion of the salts into a free amidine (with an exocyclic imine). An IR investigation of amidine tautomerism, including $\mathbf{1 2}$ and 15, showed unequivocally that such cyclic amidines exist wholly in the form having a cyclic imine and an exocyclic amino group. ${ }^{26}$ 2-Alkylamino analogues also exist with a ring imine. ${ }^{27}$ The energy difference between exocyclic and endocyclic double bonds in favour of the endocyclic isomer, long recognized for carbon-carbon double bonds, ${ }^{28}$ must represent the significant difference that favours the ring imine isomer over the exocyclic imine.

We noted the representation of $\mathbf{1 2}$ in the 12-imino form in one of the papers dealing with imidazole formation by reaction with a 2 -bromo-ketone ${ }^{16}$ - in this case pyridyl bromomethyl methanones. As indicated above, the products were assigned 2-substituted 6,7-dihydro-5Hpyrrolo[1,2- $a$ ]imidazole $\mathbf{1 3}$ structures, whereas typical amidine reactivity (see discussion above) involving the isomer 12-imino as represented in the paper, would have led to 3-substituted structures - significantly, exactly of the type described in the 2013 patent. ${ }^{19}$ We therefore decided to repeat an example of the work described in this paper ${ }^{16}$ to determine the structure unambiguously. We found that the reaction of bromomethyl pyridin-2-yl methanone 17 with amidine 12 was not a clean process but TLC analysis of the crude product showed the presence of predominantly one product, eventually obtained in $14 \%$ yield (literature ${ }^{16} 54 \%$ ) after iterative purifications by silica gel chromatography.

Examination of the product by NOESY showed a weak correlation between $\mathrm{H}-7$ and one of $\mathrm{H}_{2}-5$ (see numbering on ORTEP representation below), indicating formation of structure 18. To confirm these findings, a suitable crystalline sample of the product was prepared by slow evaporation from benzene/ $n$-pentane and subjected to X-ray crystallographic analysis (see below and in the Electronic Supplementary Information). An ORTEP representation of the structure is shown in Figure 2: it is, as the paper ${ }^{16}$ correctly states, a 2-substituted 6,7-dihydro-5 $\mathrm{H}$ pyrrolo[1,2- $a$ ]imidazole $\mathbf{1 8}$ (Scheme 7). It can be concluded that the product is formed not from tautomer 12-imino but from tautomer 12 via a first intermediate 19. 
<smiles>O=C(CBr)c1ccccn1</smiles>

17<smiles>NC1=NCC(Br)C1</smiles>

12<smiles>c1ccc(-c2cn3c(n2)CCC3)nc1</smiles>

18<smiles>N=C1CCCN1CC(=O)c1ccccn1</smiles>

19

Scheme 7. Synthesis of 2-(pyridin-2-yl)-6,7-dihydro-5H-pyrrolo[1,2-a]imidazole and first intermediate.

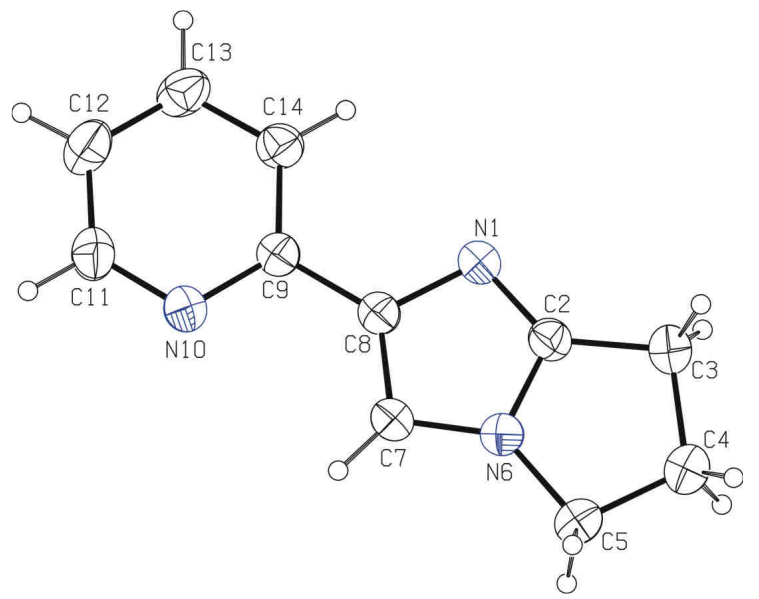

Figure 1 ORTEP representation of the structure of $\mathbf{1 8}$ with displacement ellipsoids drawn at the $30 \%$ probability level and $\mathrm{H}$ atoms shown as small spheres of arbitrary radii.

The X-ray analysis of a crystal of $\mathbf{1 8}$ showed that this compound crystallizes in the monoclinic $P 2_{1} / n$ space group with four molecules per unit cell, from which one (shown in Figure 2) constitutes a crystallographically independent part. The 6,7-dihydro-5H-pyrrolo[1,2$a$ ]imidazole (Py-Im) system is essentially planar with the largest deviations from the best leastsquares plane being -0.063(0) $\AA$ for atom C4. The dihedral angle between the plane of the Py-Im system and the pyridine ring plane is only $0.83(3)^{\circ}$.

\section{Conclusions}

We think that it is misleading in amidine chemistry to consider "regioselectivity where two nucleophilic centers are present" tautomer - there are two tautomers and the nucleophilic centre is different for each. In thinking 
about reactivity, it is important to consider both tautomers and always to remember that it may be the less stable isomer that has the more nucleophilic imine nitrogen.

\section{Experimental Section}

General. Analytical thin-layer chromatography was performed on silica gel 60 F-254 plates and visualized by UV light or iodine stain. Silica gel chromatography was performed using silica gel (60 A, particle size 40-63 nm). ${ }^{1} \mathrm{H}$ NMR spectra were recorded at $400 \mathrm{MHz}$ and ${ }^{13} \mathrm{C}$ NMR spectra at $100 \mathrm{MHz}$. The chemical shifts for ${ }^{1} \mathrm{H}$ NMR and ${ }^{13} \mathrm{C}$ NMR were referenced to TMS via residual solvent signals $\left(1 \mathrm{H}, \mathrm{CDCl}_{3}\right.$ at $7.26 \mathrm{ppm} ;{ }^{13} \mathrm{C}, \mathrm{CDCl}_{3}$ at $77.36 \mathrm{ppm} ;{ }^{1} \mathrm{H}$, DMSO-d6 at $2.45 \mathrm{ppm} ;{ }^{13} \mathrm{C}$, DMSO-d6 at $\left.39.43 \mathrm{ppm}\right)$. Microwave reactions were performed in an Initiator single mode reactor producing controlled irradiation at $2450 \mathrm{MHz}$ and the temperature was monitored using the built-in online IR sensor. LC/MS was performed on an instrument equipped with a CP-Sil $8 \mathrm{CB}$ capillary column $(50 \times 3.0 \mathrm{~mm}$, particle size $2.6 \mu \mathrm{m}$, pore size $100 \AA)$ operating at an ionization potential of $70 \mathrm{eV}$ using a $\mathrm{CH}_{3} \mathrm{CN} / \mathrm{H}_{2} \mathrm{O}$ gradient $(0.05 \% \mathrm{HCOOH})$. Accurate mass values were determined on a mass spectrometer equipped with an electrospray or electron impact ion source and 7-T hybrid ion trap (LTQ) or TOF detector, respectively. All microwave reactions were performed in sealed Pyrex microwave-transparent process vials designed for $20 \mathrm{~mL}$ reaction volumes. Reagents were purchased at the highest commercial quality and were used without further purification. Solvents used for extraction and silica gel chromatography (dichloromethane, methanol and acetone) were used without purification or removal of water.

Synthesis of 3,4-dihydro-2H-pyrrol-5-amine hydrochloride (12). Prepared via a modified version of the literature procedure. ${ }^{31}$ An ethanolic solution of ammonia $(10 \mathrm{~mL})$ was prepared by bubbling gaseous ammonia through absolute ethanol at $0{ }^{\circ} \mathrm{C}$ until a saturated solution was obtained (typically within 20 minutes). To this was added 4-chlorobutyronitrile (2.90 g, 28.01 mmol) at ambient temperature. The resulting solution was heated in a sealed Pyrex vial designed for $10-20 \mathrm{~mL}$ reaction volumes by microwave irradiation at $130{ }^{\circ} \mathrm{C}$ for $8 \mathrm{~h}$. After cooling to ambient temperature, the reaction mixture was treated with chilled diethyl ether and the resulting precipitate collected by filtration to yield a white solid $(2.02 \mathrm{~g}, 60 \%) ;{ }^{13} \mathrm{C} \mathrm{NMR}(100 \mathrm{MHz}$, DMSO-d6) $\delta 171.3,47.5,30.7$, 20.7. M.p. $148-150{ }^{\circ} \mathrm{C}$ (lit. $\left.172.4-172.8{ }^{\circ} \mathrm{C}\right) .{ }^{32}$

Synthesis of 2-(pyridin-2-yl)-6,7-dihydro-5H-pyrrolo[1,2-a]imidazole (18). Following the literature procedure, ${ }^{16}$ the title compound was obtained after iterative purifications by silica gel chromatography (DCM/MeOH/acetone 9:0.5:0.5) as a colourless solid (23 mg, 14\%); mp 129$130{ }^{\circ} \mathrm{C}$ (from benzene/n-pentane); ${ }^{1} \mathrm{H} \mathrm{NMR}\left(400 \mathrm{MHz}, \mathrm{CDCl}_{3}\right) \delta 8.49$ (ddd, J 4.9, 1.8, $0.9 \mathrm{~Hz}$, $\left.{ }^{1} \mathrm{H}\right), 7.90\left(\mathrm{dt}, J=8.0,1.1 \mathrm{~Hz},{ }^{1} \mathrm{H}\right), 7.66\left(\mathrm{ddd}, J=8.0,7.4,1.8 \mathrm{~Hz},{ }^{1} \mathrm{H}\right), 7.07(\mathrm{ddd}, \mathrm{J} 7.5,4.9,1.2$ $\left.\mathrm{Hz},{ }^{1} \mathrm{H}\right), 4.01(\mathrm{dd}, J=7.6,6.7 \mathrm{~Hz}, 2 \mathrm{H}), 3.03-2.82(\mathrm{~m}, 2 \mathrm{H}), 2.61(\mathrm{dd}, J=7.7,6.7 \mathrm{~Hz}, 2 \mathrm{H}) ;{ }^{13} \mathrm{C}$ 
NMR $\left(100 \mathrm{MHz}, \mathrm{CDCl}_{3}\right) \delta 155.3,154.1,149.4,146.9,136.9,121.6,119.2,113.7,45.1,26.4$, 23.4; MS (ESI) calcd. for $\mathrm{C}_{11} \mathrm{H}_{12} \mathrm{~N}_{3}\left[\mathrm{M}^{+} \mathrm{H}^{+}\right] \mathrm{m} / z$ 186.1022, found $m / z$ 186.1031. A single crystal of the title compound was grown using the vial-in-vial method (benzene/n-pentane) and analysed by X-ray diffraction.

Crystallographic data for 18. $\mathrm{C}_{11} \mathrm{H}_{11} \mathrm{~N}_{3}, \mathrm{M}=185.23$; monoclinic; $P 2{ }_{1} / n ; a=7.6888(3) \AA$, $b=11.9124(4) \AA, c=10.9184(4) \AA$ and $\beta=107.043(4)^{\circ} ; V=956.13(6) \AA^{3} ; Z=4$ molecules per unit cell; $D_{c}=1.287 \mathrm{~g} / \mathrm{cm}^{3} ; F(000)=392$; crystal size $0.58 \times 0.43 \times 0.12 \mathrm{~mm}$. Diffraction data were collected at 293(2) $\mathrm{K}$, using an XCALIBUR ${ }^{\mathrm{TM}} 3$ CCD diffractometer with graphitemonochromated $\mathrm{CuK}_{\alpha}$ radiation. The structure was solved by direct methods and refined by fullmatrix least-squares on $F^{2}$ using the SHELX-97 program package. ${ }^{33}$ The non-hydrogen atoms were refined anisotropically. The hydrogen atoms were first localized in difference Fourier maps and next treated as riding atoms in geometrically idealized positions, with $\mathrm{C}-\mathrm{H}$ distances of 0.93 $\left(\mathrm{Csp}^{2}\right)$ and $0.97\left(\mathrm{Csp}^{3}\right)$, and with $\operatorname{Uiso}(\mathrm{H})=1.2 \operatorname{Ueq}(\mathrm{C}) . R=0.0406$ for 1525 unique reflections with $I>2 \sigma(I) ; R=0.0444, w R=0.1196$ and $S=1.052$ for 1707 unique reflections and 128 parameters. Full crystallographic data are contained in CCDC no. $\mathbf{1 0 3 8 6 9 3}$ and can be obtained free of charge at www.ccdc.cam.ac.uk/conts/retrieving.html or from the Cambridge Crystallographic Data Centre.

\section{Hirshfeld surface analysis for 18}

In order to visualize and analyze the intermolecular interactions in the crystal structure of compound 18, the CrystalExplorer 3.1 program $^{34}$ was used. This enabled us to construct the three-dimensional Hirshfeld surface of a molecule in the crystal, ${ }^{35}$ which illustrates the interatomic contacts with distances equal to the sum of the van der Waals radii (represented as white) and with distances shorter (red) and longer (blue) than the values of this sum. This program was also used to obtain the fingerprint plots, ${ }^{36}$ which are the two-dimensional (2D) representations of this surface, and are generated based on the $d_{e}$ and $d_{i}$ distances $\left(d_{e}\right.$ and $d_{i}$ are the distances from the Hirshfeld surface to the nearest atom outside and inside the surface, respectively). For a more detailed description, please refer to the electronic supplementary information and references below.

\section{Acknowledgements}

The authors wish to thank Abdullah Al Ramahi for experimental assistance. 


\section{References}

1. Grimett, M. R. Adv. Heterocycl. Chem. 1970, 12, 103

http://dx.doi.org/10.1016/S0065-2725(08)60973-3.

2. Grimmett, M. R. Adv. Heterocycl. Chem. 1980, 27, 241 http://dx.doi.org/10.1016/S0065-2725(08)60998-8).

3. 3. Yi, N.; Huang, Q.; Liu, L. Ch. 4.02 in Comprehensive Heterocyclic Chemistry III, Joule, J. A. Volume Ed., Katritzky, A. R.; Ramsden, C. A.; Scriven, E. F. V.; Taylor, R. J. K. Series Eds. and Grimmett, M. R. in earlier editions of CHEC 1984 and 1996.

4. Grimmett, M. R. Science of Synthesis 2002, 12, 325 http://dx.doi.org/10.1055/sos-SD-012-00398.

5. Liverton, N. J.; Butcher, J. W.; Claiborne, C. F.; Claremon, D. A.; Libby, B. E.; Nguyen, K. T.; Pitzenberger, S. M.; Selnick, H. G.; Smith, G. R.; Tebben, A.; Vacca, J. P.; Varga, S. L.; Agarwal, L.; Dancheck, K.; Forsyth, A. J.; Fletcher, D. S.; Frantz, B.; Hanlon, W. A.;

Harper, C. F.; Hofsess, S. J.; Kostura, M.; Lin, J.; Luell, S.; O’Neill, E. A.; Orevillo, C. J.; Pang, M.; Parsons, J.; Rolando, A.; Sahly, Y.; Visco, D. M.; O’Keefe, S. J. J. Med. Chem. 1999, 42,2180 http://dx.doi.org/10.1021/JM9805236.

6. Tschamber, T.; Rudyk, H.; Le Nouën, D. Helv. Chim. Acta 1999, 82, 2015 http://dx.doi.org/10.1002/(SICI)1522-2675(19991110)82:11<2015::AIDHLCA2015>3.0.CO;2-Y.

7. Streith, J.; Rudyk, H.; Tschamber, T.; Tarnus, C.; Strehler, C.; Deredas, D.; Frankowski, A Eur. J. Org. Chem. 1999, 893 http://dx.doi.org/10.1002/(SICI)1099-0690(199904)1999:4<893::AID-EJOC893>3.0.CO;2\#.

8. Graczyk, P. P.; Khan, A.; Bhatia, G. S.; Palmer, V.; Medland, D.; Numata, H.; Oinuma, H.; Catchick, J.; Dunne, A.; Ellis, M.; Smales, C.; Whitfield, J.; Neame, S. J.; Shah, B.; Wilton, D.; Morgan, L.; Patel, T.; Chung, R.; Desmond, H.; Staddon, J. M.; Sato, N.; Inoue, A.

Bioorg. Med. Chem. Lett. 2005, 15, 4666 http://dx.doi.org/10.1016/j.bmcl.2005.07.076).

9. Shilcrat, S. C.; Mokhallalati, M. K.; Fortunak, J. M. D.; Pridgen, L N. J. Org. Chem. 1997, 62,8449 http://dx.doi.org/10.1021/JO971304F.

10. Raczynska E. D.; Laurence, C. Analyst 1992, 117, 375 http://dx.doi.org/10.1039/AN9921700375.

11. Prevorsek, D. C. J. Phys. Chem. 1962, 66, 769 http://dx.doi.org/10.1021/j100811a001.

12. Prevorsek, D. C. Bull. Soc. Chim. Fr. 1958, 788

13. Raczynska, E.; Oszczapowicz, J. Tetrahedron 1985, 41, 5175 http://dx.doi.org/10.1016/S0040-4020(01)96762-6. 
14. Jackman, L. M.; Jen, T. J. Am. Chem. Soc. 1975, 97, 2811

http://dx.doi.org/10.1021/ja00843a033.

15. Langlois, M.; Guillonneau, C.; Man, T. V.; Meingen, J. P.; Maillard, J. J. Heterocycl. Chem. 1982, 19, 193

http://dx.doi.org/10.1002/jhet.5570190137.

16. Callahan, J. F.; Burgess, J. L.; Fornwald, J. A.; Gaster, L. M.; Harling, J. D.; Harrington, F. P.; Heer, J.; Kwon, C.; Lehr, R.; Mathur, A.; Olson, B. A.; Weinstock, J.; Laping, N. J. J. Med. Chem. 2002, 45, 999 http://dx.doi.org/10.1021/jm010493y.

17. Demchenko, A. M.; Nazarenko, K. G.; Andrushko, A. P.; Fediyuk, D. V.; Krasovsky, A. N.; Yagupolsky, L. M. Chem. Heterocycl. Compd. 2003, 39, 965 http://dx.doi.org/10.1023/A:1026114908997.

18. Calderwood, D. J.; Bonafoux, D. F.; Burchat, A.; Ding, P.; Frank, K. E.; Hoemann, M. Z.; Mullen, K. D.; Davis, H. M. WO 20009005675 for one example from many patent reports.

19. Wang, Z.; Nelson, J. B.; Nguyen, M. M. B.; Lazo, J. S.; Johnston, P. A.; Wipf, P. WO2013055793.

20. Claffey, M. M.; Goldstein, S. W.; Jung, S.; Nagel, A.; Shulze, V. WO2007034282 for one example from several patent reports.

21. Donohoe, T. J.; Kabeshov, M. A.; Rathi, A. H.; Smith, I. E. D. Org. Biomol. Chem. 2012, 10, 1093 http://dx.doi.org/10.1039/c1ob06587d.

22. Sonnenschein, H.; Schmitz, E. Synthesis 1989, 443 http://dx.doi.org/10.1055/s-1989-27280.

23. Mitchell, R. E.; The, K. L. Org. Biomol. Chem. 2005, 3, 3540 http://dx.doi.org/10.1039/b509319h.

24. Moore, W. M.; Webber, R. K.; Fok, K. F.; Jerome, G. M.; Connor, J. R.; Manning, P. T.; Wyatt, P. S.; Misko, T. P.; Tjoeng, F. S.; Currie, M. G. J. Med. Chem. 1996, 39, 669 http://dx.doi.org/10.1021/JM950766N.

25. Shankaran, K.; Donnelly, K. L.; Shah, S. K.; Guthikonda, R. N.; MacCoss, M.; Humes, J. L.; Pacholok, S. G.; Grant, S. K.; Kelly, T. M.; Wong, K. K. Bioorg. Med. Chem. Lett. 2004, 14, 4539 http://dx.doi.org/10.1016/j.bmcl.2004.06.033.

26. Sieveking, H. U.; Lüttke, W. Justus Liebigs Ann. Chem. 1977, 189 http://dx.doi.org/10.1002/jlac.197719770202.

27. Perrin, C. L.; Nuñez, O. J. Am. Chem. Soc. 1986, 108, 5997 http://dx.doi.org/10.1021/ja00279a055.

28. Turner, R. B.; Garner, R. H. J. Am. Chem. Soc. 1958, 80, 1424 http://dx.doi.org/10.1021/ja01539a036.

29. Bernstein, J.; Davis, R. E.; Shimoni, L.; Chang, N.-L. Angew. Chem. Int. Ed. 1995, 34, 1555 http://dx.doi.org/10.1002/anie.199515551. 
30. Kaugars, G.; Martin, S. E.; Nelson, S. J.; Watt, W. Heterocycles 1994, 38, 2593 http://dx.doi.org/10.3987/COM-94-6838.

31. Moriconi, E. J.; Cevasco, A. A. J. Org. Chem. 1968, 33, 2109 http://dx.doi.org/10.1021/jo01269a091.

32. Grierson, J. R., Brockenbrough, J. S., Rasey, J. S., Wiens, L., Veselle, H. Nucleosides Nucleotides Nucleic Acids. 2010, 29, 49 http://dx.doi.org/10.1080/15257770903451603.

33. Sheldrick, G. M. Acta Crystallogr. Sect. A Found. Crystallogr. 2008, 64, 112-122 http://dx.doi.org/10.1107/S0108767307043930.

34. Wolff, S. K.; Grimwood, D. J.; McKinnon, J. J.; Turner, M. J.; Jayatilaka, D.; Spackman, M. A. CrystalExplorer (Version 3.1), 2012, University of Western Australia.

35. Spackman, M. A.; Jayatilaka, D. CrystEngComm 2009, 11, 19 http://dx.doi.org/10.1039/b818330a.

36. Spackman, M. A.; McKinnon, J. J. CrystEngComm 2002, 4, 378 http://dx.doi.org/10.1039/b203191b. 